\title{
Distance Learning in Higher Education Institutions: An Analysis of Students Perspective during Covid-19 Pandemic
}

\author{
Husni Mubarok ${ }^{*}$, Nina Sofiana \\ English Education Study Program, Universitas Islam Nahdlatul Ulama Jepara, Indonesia
}

Received January 5, 2021; Revised February 18, 2021; Accepted March 12, 2021

\section{Cite This Paper in the following Citation Styles}

(a): [1] Husni Mubarok, Nina Sofiana, "Distance Learning in Higher Education Institutions: An Analysis of Students Perspective during Covid-19 Pandemic," Universal Journal of Educational Research, Vol. 9, No. 3, pp. 630 - 637, 2021. DOI: 10.13189/ujer.2021.090322.

(b): Husni Mubarok, Nina Sofiana (2021). Distance Learning in Higher Education Institutions: An Analysis of Students Perspective during Covid-19 Pandemic. Universal Journal of Educational Research, 9(3), 630 - 637. DOI: 10.13189/ujer.2021.090322.

Copyright $\odot 2021$ by authors, all rights reserved. Authors agree that this article remains permanently open access under the terms of the Creative Commons Attribution License 4.0 International License

\begin{abstract}
The Covid-19 pandemic has spread to almost all countries, as well as Indonesia. The pandemic is changing the way of learning in universities from face-to-face learning to online learning. This study aimed to determine the extent to which distance learning is applied in Indonesian universities in the aspects of planning, teaching, and assessment from the students' perspective. The approach used in this research was qualitative with a cross sectional survey research design to describe the phenomenon in the research subject. This research data were collected through questionnaires with three main indicators distributed to university students in the coastal areas of the Central Java province of Indonesia. There were 105 respondents becoming a research sample which was divided into three university clusters; public universities, private universities, and colleges. The results showed that in the planning stage, there were adjustments made by the lecturers even though they required more efforts. In teaching phase, lecturers changed the learning way from face to face to online by using various kinds of information systems and applications. In assessment phase, students got input both directly and indirectly through the information system and applications used.
\end{abstract}

Keywords Distance Learning, Higher Education Institution

\section{Introduction}

On March 12, 2020, Indonesia was firstly to confirm a Covid-19 case. The high spread of the virus, then, forced classrooms to close under the physical distancing policy. In response to this issue, the Education and Culture Ministry took a crucial step by changing face-to-face learning into distance learning. Thus, all education institutions must respond to this transition with tremendously innovative plans for distance learning to ensure students are able to catch up their lessons smoothly. The question arises whether or not the students are ready with this change.

Before the massive distance learning via online occurred in Indonesian universities, online system called learning management system (LMS) has been introduced and implemented in some universities in Indonesia. Then the LMS use is popular with Spada (sistem pembelajaran daring Indonesia or Indonesia online learning system) which is adopted to some universities either public or private universities. To make students and academics easy to access Spada, its hosting are usually begun with Spada and university name. The application of Spada in learning system has been mandated by government where the Indonesia education policy has put digital literacy in national curriculum as one of the skill beside literacy and numerical skill that must be acquired by students and teachers in 21 st century learning and teaching skills in 
primary and secondary schools [1].

Some challenges arises when online learning is implemented. One of them is the changing of traditional form to virtual form where the physical space of traditional form changes into virtual space of the internet platform [2]. Besides that, teachers also play important roles in virtual teaching as stated by [3] where they should not only assume the roles of transmitting knowledge, but also play the roles of leader and accompanier through the effective guidance and communication.

Some researchers have conducted studies of distance learning. Carter [4] found that learning through online learning model did impact practice on professional nurses. Shraim [5] investigated that online examination are suitable for conducting formative assessment rather than summative assessment. Mobile devices such as smartphones and tablets are primarily designed for receiving information rather than producing information, although they are often seen as a means to encourage independent learning [6]. Young \& Donovan [7] add that technology is helpful for students who have problems with reading comprehension and decoding. It shows that when reading students receive information from written text rather than producing information. Most English teachers in Indonesia believed that the integration of technology is important in teaching and learning, but teachers did not have any competence in ICT pedagogy [1]. It contradicts with the real teaching and learning in class.

Distance education is not a new paradigm in learning. However, due to the Covid-19 pandemic, the learning system has become the best choice. Many educational institutes in the United States offered the study through distance education [8]. Distance learning (also called as e-learning) is a learning process in which a teacher and students are disconnected spatially and by time [9-10]. Distance learning happens when the teachers and students do not meet each other in a classroom setting during a substantial part of the instructional process, and the instructional gap created by the physical separation of the teachers and students is connected by technology [8]. Although distance learning does not ask teachers and students to have face to face interaction, it could be included in social learning theory because it contains community based learning which is assessed by the use of technology. Vygotskyan suggested that social interaction is a necessary and central component of learning and not just supplementary [11]. Therefore, as a social learning theory, a learning environment cannot be an isolated world in which students gain knowledge in order to apply it outside of the classroom [12]. Baker in Carter [4] mentions that interaction and engagement must be on teaching and learning process because they are the outcomes of a process called instructional design. To sum up, teachers and students could build a community based learning if they follow in a specific domain, participate in learning activities, and share ideas in discussion.
It is online learning by utilizing technology, including television, internet, video, tapes, software, cameras, email, chat rooms, website, etc. Besides, zoom, Microsoft teams, and gamification could be used as teaching methods during the pandemic [13]. Zoom is used for audio or video conference meetings with large participants and teaching classes between teachers and students. Microsoft team is built-in meeting features to successfully hold classes and share documents by attaching power point presentation (PPT), websites, video, audio, and other files. Gamification is the use of game design elements outside of a game environment [13].

In the teaching and learning process, the teacher may choose synchronous or asynchronous model of teaching. Synchronous and asynchronous model are modes of communication to maintain interaction between teacher and students in online learning environment [14]. He defines synchronous learning that activities that involve a teacher and students engaging in learning at the same time, such as instant messaging, live chats, and video conferencing for real time learning. Meanwhile, asynchronous learning is a student-centered model of learning using online resource to facilitate information which can be read, seen, and heard by the learners at any time and places. These models are believed to be able to be utilized in the teaching and learning process during the Covid-19 pandemic. Therefore, education institution including higher education must be prepared with new challenges to the teaching and learning process of distance learning.

To be effective, there are some principles to implement distance learning [15]. The teachers need to be able to encourage student-faculty contact, foster cooperation among students and active learning, provide prompt feedback, highlight time on task, connect high expectations, and appreciate diverse talents and ways of learning. Therefore, a study need to be conducted whether the teachers as facilitators have applied it effectively or not from students' perspective.

\subsection{Purpose of the Study}

Based on the elaboration of related literatures and previous studies above, this study aims to determine the extent to which distance learning is applied in Indonesian universities in the aspects of planning, teaching, and assessment from the students' perspective due to Covid-19 pandemic. The result of this study is expected to become a basis for lecturers in higher education institutions to determine adaptive learning planning, online media or applications used in teaching, and appropriate assessment during Covid-19 pandemic. The research question was "How do students perceive and describe their experience during the implementation of distance learning from the planning, implementation, and evaluation?" 


\section{Methods}

\subsection{Research Design}

This research was conducted by using a cross sectional survey design which was used to produce a snapshot of a population at a particular point in a time [16]. The purpose of this survey research was to obtain an overview of the population under study. Therefore, this study did not look for relationships between variables. This research data was collected once at a time and then was analyzed using quantitative and qualitative approaches.

\subsection{Population and Sample}

The population of this research was university students located in the coastal area of Central Java province, Indonesia. Due to the large number of populations, this study used a sample by means of cluster sampling where the population was grouped into three groups of universities; public universities, private universities, and colleges. So, each group consisted of 35 respondents that were taken as a sample with a total of 105 respondents who were divided into three university clusters.

\subsection{Data Collection and Analysis}

This research data was collected through a questionnaire distributed online through Google form. The questionnaire used was the combination of a closed and open questionnaire in which the respondents needed to answer "Yes" or "No" for the 20 closed-ended questions and they were also allowed to give a free-form answer for the 5 open-ended questions. The questionnaire was divided into three indicators, namely; planning, teaching, and assessment. These three indicators were carried out online when the Covid-19 pandemic was still ongoing. Table 1 is the variables used in this study.

Table 1. Questionnaire's Indicators

\begin{tabular}{|c|c|}
\hline Indicators & Sub-indicator \\
\hline Planning & Lesson plan \\
\hline & Learning materials \\
& Learning process adjustment \\
Teaching & Learning media \\
& Students-teacher interaction \\
& Time management \\
& Students' participation \\
\hline \multirow{2}{*}{ Assessment } & Evaluation \\
& Feedback \\
\hline
\end{tabular}

Before the instrument was used to collect data, it was first validated using construct validity by education and media experts. The validation results showed that the instrument was in a good category and could be used to collect data.

\subsection{Data Analysis}

The data was analyzed quantitatively and qualitatively. Frequencies and percentages of the closed-ended questionnaire were computed first to find out the implementation of the distance learning during the Covid-19 virus pandemic, while the data of open-ended questionnaires were analyzed through the steps of data reduction, display, and verification.

\section{Result and Discussion}

105 students from 3 universities in the coastal area of Central Java province, Indonesia have participated in the study. Their perceptions toward the implementation of distance learning during the Covid-19 pandemic are shown in Table 2.

\subsection{Lesson Plan of Distance Learning Implementation}

The plan of teaching and learning activities, during the Covid-19 pandemic, is important to have more effective teaching and learning. From the result of questionnaire, it indicates that most of students from the three universities state that the lesson plan made by the teacher during the distance learning has been adjusted to the conditions of the Covid-19 pandemic. $94 \%$ teachers from all respondents have written the aims and objectives, the materials, the media, and the method of the courses clearly. The teaching and learning activities are also well planned. Furthermore, the students feel that the activities are more flexible. However, the students mention that there are $6 \%$ teachers who still do not change their lesson plans. They still use the existing lesson plans that are appropriate only for face-to-face learning. Therefore, some activities do not apply in the teaching and learning process or even the teachers implement the teaching and learning process not based on their lesson plan. In addition, the students state that some teachers are not ready with the change of teaching and learning process. The activities burden the students with some assignments to complete. The condition may be caused by the sudden shift from face-to-face learning to distance learning due to the outbreak of Covid-19. The teachers still need time to adjust the situation, especially for the teachers who are still not familiar with the technology. However, all teachers, due to the condition, must adapt the learning situation as quickly as possible started from the lesson plan because it is the crucial stage that must be carried out by the teachers to make the learning activities more organized [17]. 
Table 2. Students' Perception

\begin{tabular}{|c|c|c|c|c|c|c|}
\hline Indicators & Responses & $\begin{array}{c}\text { Group } 1 \\
\text { N }(\%) \\
\end{array}$ & $\begin{array}{c}\text { Group } 2 \\
\mathbf{N}(\%) \\
\end{array}$ & $\begin{array}{c}\text { Group } 3 \\
\mathbf{N}(\%) \\
\end{array}$ & $\begin{array}{c}\text { All students } \\
\mathbf{N}(\%)\end{array}$ & Mean \\
\hline \multicolumn{7}{|l|}{ Lesson Plan } \\
\hline \multirow{2}{*}{ Suitability } & Yes & $30(86)$ & $30(86)$ & $32(91)$ & $92(88)$ & $32(91)$ \\
\hline & No & $5(14)$ & $5(14)$ & $3(9)$ & $13(12)$ & $3(9)$ \\
\hline \multirow{2}{*}{ Clarity } & Yes & $33(94)$ & $29(83)$ & $32(91)$ & $94(90)$ & $32(91)$ \\
\hline & No & $2(6)$ & $6(17)$ & $3(9)$ & $11(10)$ & $3(9)$ \\
\hline \multicolumn{7}{|l|}{ Learning Material } \\
\hline \multirow{2}{*}{ Meaning } & Yes & $17(49)$ & $25(71)$ & $29(83)$ & $71(68)$ & $25(71)$ \\
\hline & No & $18(51)$ & $10(29)$ & $6(17)$ & $34(32)$ & $10(29)$ \\
\hline \multirow{2}{*}{ Easiness } & Yes & $20(57)$ & $21(60)$ & $18(51)$ & $59(56)$ & $25(71)$ \\
\hline & No & $15(43)$ & $14(40)$ & $17(49)$ & $46(44)$ & $10(29)$ \\
\hline \multirow{2}{*}{$\begin{array}{l}\text { Students' concentration } \\
\text { toward the material }\end{array}$} & Yes & $23(66)$ & $18(51)$ & $23(66)$ & $64(61)$ & $25(71)$ \\
\hline & No & $12(34)$ & $17(49)$ & $12(34)$ & $41(39)$ & $10(29)$ \\
\hline \multicolumn{7}{|l|}{ Learning Process } \\
\hline \multirow{2}{*}{$\begin{array}{l}\text { The effective and creative } \\
\text { learning }\end{array}$} & Yes & $29(83)$ & $28(80)$ & $28(80)$ & $85(81)$ & $28(80)$ \\
\hline & No & $6(17)$ & $7(20)$ & $7(20)$ & $20(19)$ & $7(20)$ \\
\hline \multirow{2}{*}{$\begin{array}{c}\text { The varying learning activity } \\
\text { and assignment }\end{array}$} & Yes & $31(89)$ & $26(74)$ & $29(83)$ & $86(82)$ & $28(80)$ \\
\hline & No & $4(11)$ & $9(26)$ & $6(17)$ & $19(18)$ & $7(20)$ \\
\hline \multicolumn{7}{|l|}{ Learning Media } \\
\hline \multirow{2}{*}{ Online application } & Yes & $35(100)$ & $35(100)$ & $35(100)$ & $105(100)$ & $35(100)$ \\
\hline & No & $0(0)$ & $0(0)$ & $0(0)$ & $0(0)$ & $0(0)$ \\
\hline \multirow{2}{*}{$\begin{array}{c}\text { The use of online learning } \\
\text { system facilitated by the } \\
\text { university }\end{array}$} & Yes & $34(97)$ & $34(97)$ & $27(77)$ & $95(90)$ & $34(97)$ \\
\hline & No & $1(3)$ & $1(3)$ & $8(23)$ & $10(10)$ & $1(3)$ \\
\hline \multirow{2}{*}{$\begin{array}{l}\text { The use of media in practicum } \\
\text { classes }\end{array}$} & Yes & $21(60)$ & $25(71)$ & $23(66)$ & $69(66)$ & $25(71)$ \\
\hline & No & $14(40)$ & $10(29)$ & $12(34)$ & $36(34)$ & $10(29)$ \\
\hline \multirow{2}{*}{ The easiness of access } & Yes & $29(83)$ & $29(83)$ & $31(89)$ & $89(85)$ & $29(83)$ \\
\hline & No & $6(17)$ & $6(17)$ & $4(11)$ & $16(15)$ & $6(17)$ \\
\hline \multirow{2}{*}{ The use of interesting media } & Yes & $26(74)$ & $21(60)$ & $25(71)$ & $72(69)$ & $25(71)$ \\
\hline & No & $9(26)$ & $14(40)$ & $10(29)$ & $33(31)$ & $10(29)$ \\
\hline \multicolumn{7}{|l|}{ Students-Teacher Interaction } \\
\hline \multirow{2}{*}{$\begin{array}{l}\text { The availability of discussion } \\
\text { forum }\end{array}$} & Yes & $33(94)$ & $29(83)$ & $26(74)$ & $88(84)$ & $29(83)$ \\
\hline & No & $2(6)$ & $6(17)$ & $9(26)$ & $17(16)$ & $6(17)$ \\
\hline \multirow{2}{*}{$\begin{array}{l}\text { Students' activeness in } \\
\text { discussion }\end{array}$} & Yes & $29(83)$ & $29(83)$ & $27(77)$ & $85(81)$ & $28(80)$ \\
\hline & No & $6(17)$ & $6(17)$ & $8(23)$ & $20(19)$ & $7(20)$ \\
\hline \multicolumn{7}{|l|}{ Time Management } \\
\hline \multirow{2}{*}{ Adherence to schedule } & Yes & $32(91)$ & $29(83)$ & $31(89)$ & $92(88)$ & $30(90)$ \\
\hline & No & $3(9)$ & $6(17)$ & $4(11)$ & $13(12)$ & $5(10)$ \\
\hline Time flovibility 150 & Yes & $23(66)$ & $25(71)$ & $28(80)$ & $76(72)$ & $25(71)$ \\
\hline rime nexiontity & No & $12(34)$ & $10(29)$ & $7(20)$ & $29(28)$ & $10(29)$ \\
\hline Students' Participation & & & & & & \\
\hline Always doing the assignment & Yes & $34(97)$ & $35(100)$ & $35(100)$ & $104(99)$ & $34(97)$ \\
\hline given by the teacher & No & $1(3)$ & $0(0)$ & $0(0)$ & $1(1)$ & $1(3)$ \\
\hline Always learning the material & Yes & $32(91)$ & $31(89)$ & $35(100)$ & $98(93)$ & $32(91)$ \\
\hline shared by the teacher & No & $3(9)$ & $4(11)$ & $0(0)$ & $7(7)$ & $3(9)$ \\
\hline The indenendence in learning & Yes & $24(69)$ & $24(69)$ & $28(80)$ & $76(72)$ & $25(71)$ \\
\hline 1ne independence in learning & No & $11(31)$ & $11(31)$ & $7(20)$ & $29(28)$ & $10(29)$ \\
\hline Assessment & & & & & & \\
\hline Feedback of evaluation given & Yes & $32(91)$ & $31(89)$ & $29(83)$ & $92(88)$ & $31(89)$ \\
\hline by the teacher & No & $3(9)$ & $4(11)$ & $6(17)$ & $13(12)$ & $4(11)$ \\
\hline
\end{tabular}




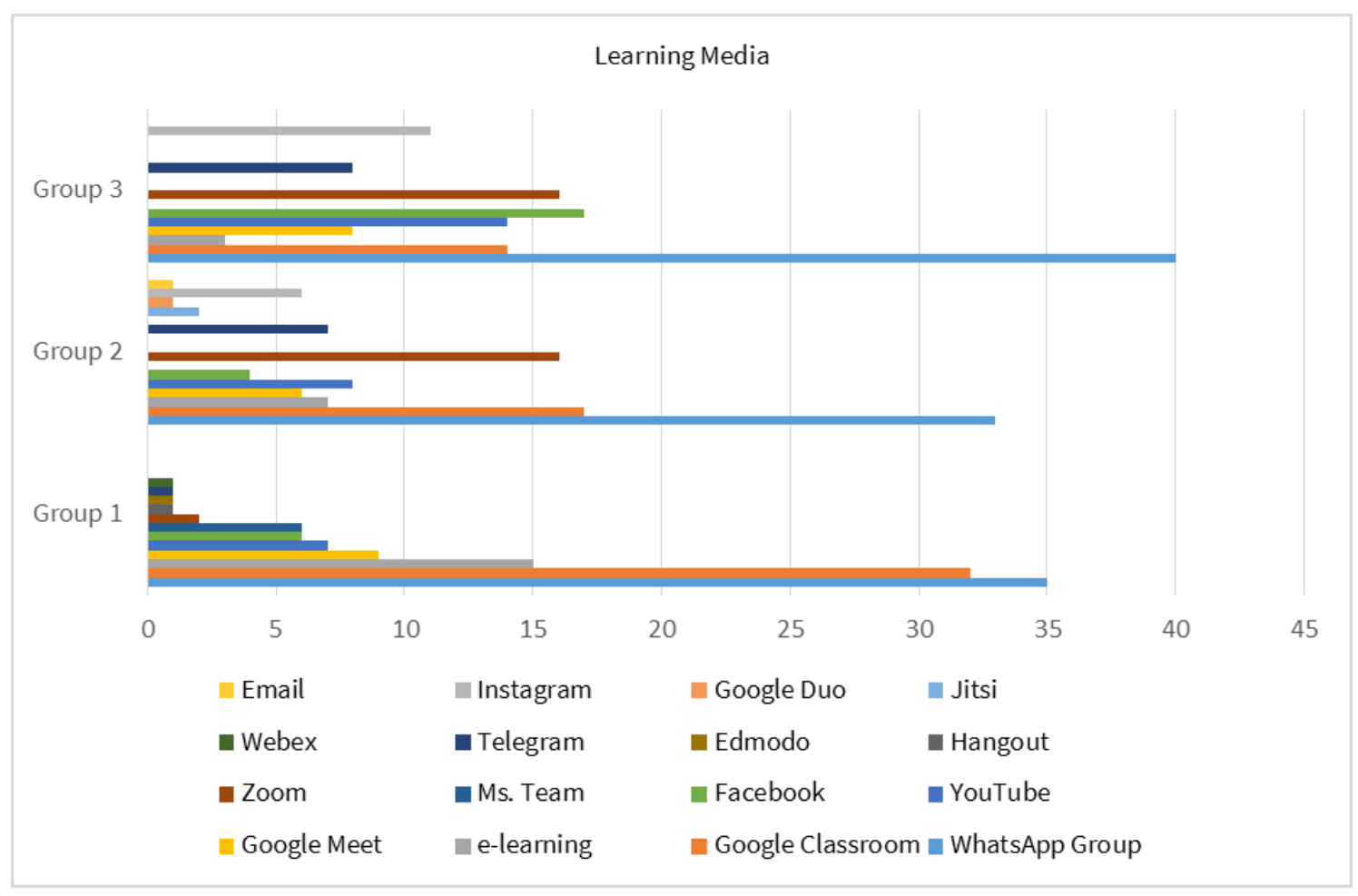

Figure 1. Learning Media

\subsection{Teaching and Learning Process of Distance Learning Implementation}

The teaching and learning process observed in this study includes the delivery of the materials, the adjustment of learning process, the media, the students-teacher interaction, the time management, and the students' participation. The key element in implementing learning during the Covid-19 pandemic is the transformation of learning media. Therefore, all teachers $(100 \%)$ use online application in teaching. Chart 1 shows the learning platforms used by the teacher during teaching and learning due to the transformation of learning from face-to-face learning into distance learning. WhatsApp Group (WAG) and Google Classroom occupy the highest position as media in delivering the materials. WAG becomes the most popular one since it is the simplest and easiest media to use [18]. The other learning platforms utilized by the teacher in delivering the materials are e-learning, Google Meet, YouTube, Facebook, Ms. Team, Zoom, Hangout, Edmodo, Telegram, Webex, email, Instagram, Google Duo, and Jitsi,. Besides, the teachers $(95 \%)$ also employ the online learning system facilitated by the university. The system used by the universities is a learning platform of Moodle or Learning Management System (LMS). However, some teachers $(10 \%)$ do not use this platform because the operation is not simple as WAG and it is also still new for the students. Moreover, the chosen media by the teachers, according to the students, are easy to access (85\%) and interesting $(72 \%)$. Some $(66 \%)$ are also can be used for practicum classes and the rest are not. Teachers usually use social media like Facebook, Instagram, and YouTube for practical courses. These media are effective for theoretical and practical course; however, for practical course and field course, they are less effective [19].

Based on the students' perspectives, the learning materials delivered during the distance learning provide meaningful learning experiences for students. $71 \%$ students do not feel burdened with assigned tasks, while $29 \%$ students feel that the teachers give too many assignments to them. In addition, according to the students from the result of open-ended questionnaire, some teachers are able to convey material well. Therefore, students can understand the material easily. The teachers, in the teaching and learning process, ask students to be active in group chat class discussions. To make them so, the teachers will assume that they are not present in learning for passive students and provide additional score rewards for active students. At the end of the discussion, the teacher reviews and discusses what the students have discussed. However, some students explain that the teacher, in discussion time, sometimes do not conclude the materials in which it makes the students not know whether their opinions are correct or not.

Then, almost half participants (46\%) think that the material presented by the lecturer is difficult to understand. In delivering materials, the teachers usually use WAG and Google Classroom to discuss the topics of the course through typing the messages, voice notes, pictures, or sharing the materials from power point file with the audio and the YouTube link. Besides, the teachers also utilize 
Google Meet, Google Duo, Jitsi, Webex, Hangout, Ms. Teams, or Zoom in teaching synchronously (92\%). By using technology, the students are welcomed to ask everything about the materials to the teachers without being limited by time and space. The asynchronous learning let the students to have the flexibility to access the materials $(76 \%)$ and encourage them to be independent learners $(72 \%)$. In addition, the students are also frequently asked to have presentation using WAG, while the teacher only pays attention to the presentation and s/he adds some corrections if the students still have not understood about the materials. This activity sometimes makes the students get difficulty in understanding the materials since between the teacher and students cannot interact directly. Furthermore, the students say that some teachers only send the materials and assignment without explaining them.

In addition, although 64\% students can concentrate when the teachers deliver the materials, the rest of them cannot. It happens because the due dates of some assignments are in the same time. It makes them lose time to read the literature provided by the teacher. Some focus more on completing the assignments than on understanding the materials. Therefore, the students expect that the teacher does not give them some stressful assignments in the end of the lesson.

Related to the students-teacher interaction during the learning, $88 \%$ students mention that the teachers provide an online discussion forum to maintain students' engagement in distance learning, and $85 \%$ students are also active in the discussion. Having online discussion is an alternative way for effective communication between the teacher and the students [20] in the distance learning. The result also indicates that $16 \%$ teachers do not ask the students to have discussion. The teachers may only give the material without encouraging students-centered learning. Additionally, although the teachers have supported the students to be active, there are still $19 \%$ passive students. It happens because their concentrations are distracted with the unfinished assignments. The students are not active in participating in the discussion because they are still working on another assignments that must be completed immediately. Though, 93\% students always learn the material shared by their teachers and 99\% students complete their assignment.

\subsection{Assessment of Distance Learning Implementation}

Learning assessment is crucial to evaluate whether the teaching and learning goals are being met; and feedback are influential tool to encourage students to learn. Based on the result of questionnaire, the $88 \%$ students get the feedback for each evaluation given by the teachers. The teachers provide direct and indirect feedback during the learning. The direct feedbacks, for example, are given on a synchronous session. The teachers give a case and the students need to solve it; in the end of the learning the teachers conclude the materials and give feedback toward the students' answer. Also, when the students have presentation, the teachers always give feedback toward the materials presented. Besides, the teachers also encourage the students to provide feedback to one another. In this case, not only from the teachers, students learn from their peers.

In addition, according to the students, teachers provide written feedback on each assignment submitted to online platforms. In this indirect feedback, teachers not only give numerical marks but they also add narrative feedback. It is essential because feedback in the narrative form is more understandable [21]. However, due to its advantage, there are still $12 \%$ teachers who do not give any feedback to the students.

\subsection{The Relationship between Variables}

Table 3. Students' Perception Model Summary

\begin{tabular}{|c|c|c|c|c|}
\hline Model & $\mathrm{R}$ & R Square & $\begin{array}{c}\text { Adjusted R } \\
\text { Square }\end{array}$ & $\begin{array}{c}\text { Std. Error of the } \\
\text { Estimate }\end{array}$ \\
\hline 1 &, $095^{\mathrm{a}}$ &, 009 &,- 010 & 6,751 \\
\hline
\end{tabular}

The table 3 explains the percentage of the influence of the independent variables on the dependent variable. The coefficient of determination is 0.009 . It means that the influence of the independent variable on the dependent variable is $0.9 \%$, while $99.1 \%$ is influenced by other variables. Thus, it means that the ability of the learning assessment carried out by the lecturers based on the students perspective is more influenced by other variables and is not influenced by the planning variables that have been compiled and the implementation of learning that has been carried out by the lecturers. This is natural because the large value of the correlation coefficient between variables shows that there is no significant correlation. In other words, between variables are uncorrelated.

Table 4. Anova ${ }^{\mathrm{a}}$

\begin{tabular}{|c|c|c|c|c|c|c|}
\hline \multicolumn{2}{|c|}{ Model } & $\begin{array}{c}\text { Sum of } \\
\text { Squares }\end{array}$ & df & $\begin{array}{c}\text { Mean } \\
\text { Square }\end{array}$ & F & Sig. \\
\hline \multirow{3}{*}{1} & Regression & 42,347 & 2 & 21,173 &, 465 &, $630^{\mathrm{b}}$ \\
\cline { 2 - 7 } & Residual & 4648,168 & 102 & 45,570 & & \\
\cline { 2 - 7 } & Total & 4690,514 & 104 & & & \\
\hline
\end{tabular}

The amount of F-count in the table above is 0.465 , while the significance is 0.630 . The significance of the Anova table is greater than 0.05 , so null hypothesis is accepted and working hypothesis is rejected. Thus, the variation in the value of the independent variable cannot explain the variation in the value of the dependent variable. In other words, the variable value of the planning and teaching cannot predict the learning assessment ability variable carried out by the lecturers based on the students' 
perspective. This is further strengthened by the interpretation of the regression equation below.

Table 5. Coefficients ${ }^{\mathrm{a}}$

\begin{tabular}{|c|c|c|c|c|c|c|}
\hline & \multirow[t]{2}{*}{ Model } & \multicolumn{2}{|c|}{$\begin{array}{l}\text { Unstandardized } \\
\text { Coefficients }\end{array}$} & \multirow{2}{*}{\begin{tabular}{|c|}
$\begin{array}{c}\text { Standardized } \\
\text { Coefficients }\end{array}$ \\
Beta \\
\end{tabular}} & \multirow[t]{2}{*}{$\mathrm{t}$} & \multirow[t]{2}{*}{ Sig. } \\
\hline & & B & Std. Error & & & \\
\hline \multirow{3}{*}{1} & (Constant) & 79,028 & 11,305 & & 6990 &, 000 \\
\hline & $\begin{array}{l}\text { Planning } \\
\text { (X1) }\end{array}$ &,- 109 & ,113 &,- 101 &,- 957 &, 341 \\
\hline & $\begin{array}{l}\text { Teaching } \\
\text { (X2) }\end{array}$ & ,035 & , 142 & ,026 & ,246 & ,806 \\
\hline
\end{tabular}

The table above shows that the variable planning value with the t-test coefficient is -0.957 , while the significance level of 0.341 is much greater than 0.05 . This means that the effect of the planning value on the assessment value is not significant. The t-test coefficient of the teaching value is 0.246 , while the significance is 0.806 , which is greater than 0.05 . This means that the effect of teaching value is not significant.

Theoretically, the planning and implementation of learning affect learning assessment. However, after regression analysis was carried out, the planning and implementation of learning did not affect the learning assessment from the students' perspective. This is possibly caused by the existence of other variables or the assessment instruments used by the lecturers that have not met the principles of validity and reliability.

\section{Conclusions}

The teachers, based on students' perspective, have implemented distance learning during Covid-19 pandemic well. However, most of teachers have successfully adapted to the change of lesson plan, teaching and learning process including the learning media, and assessment. However, in implementing distance learning flawlessly, the teachers need to consider the conditions of the students in remote area. They need to choose learning platforms that are easily and cheaply accessed by the students. Further research needs to be conducted with alarge sample of the students. Direct observation is also necessary to carry out to check in-depth the distance learning implementation.In addition, based on the regression analysis, it was found that the planning and implementation of learning carried out by lecturers did not affect the learning assessment. For further research, it would be better to also analyze the validity and reliability of the assessment instruments made by the lecturers to complement the results of the analysis between the variables.

\section{REFERENCES}

[1] G. N. Hafifah, G. H Sulistyo. Teachers' ICT Literacy and ICT Integration in ELT in the Indinesian Higher Education Setting, Turkish Online Journal of Distance Education, Vol.2, No.3, pp. 186-198, 2020.

[2] X. Cheng. (2020). Challenges of "School's Out, But Class's On" to School Education: Practical Exploration of Chinese Schools during the COVID-19 Pandemic, SIEF Journal, Vol.5, No.2, pp. 501-516, 2020. https://doi.org/10.15354/si ef.20.ar043.

[3] J. Yao, J. Rao, T. Jiang, C. Xiong. What Role Should Teachers Play in Online Teaching during the COVID-19 Pandemic? Evidence from China, Sci Insight Edu, Vol.5, No.2, 2020. https://doi.org/10.15354/sief.20.ar035.

[4] L. Carter. Perceptions of the Impact of Online Learning as a Distance - based Learning Model on the Professional Practices of Working Nurses in Northern Ontario Perceptions de l' impact de l' apprentissage en ligne comme modèle d' apprentissage à distance sur les, Canadian Journal of Learning and Technology, Vol.42, No.3, pp. 1-15, 2016.

[5] K. Shraim. Online Examination Practices in Higher Educational institutions: Learners' Perspectives, Turkish Online Journal of Distance Education, Vol.20, No.4, pp. 185-196, 2019.

[6] M. Frenette, K. Frank, Z, Deng. COVID-19 Pandemic: School Closures and the Online Preparedness of Children, Statcan, 45280001, 2020.

[7] B. J. Young, W. Donovan. Shifting Special Needs Students to Online Learning in the COVID-19 Spring Challenges for students, families, and teachers, Pioneer Institute, 2020.

[8] M. Rahman, R. Karim, F, Byramjee. Prospect of distance learning. Journal of International Education Research, Vol.11, No.3, pp. 173-178, 2015.

[9] H. C. Liu, J. R.Yen. Effects of Distance Learning on Learning Effectiveness. Eurasia Journal of Mathematics, Science and Technology Education, Vol.10, No.6, pp. 575-580, 2014. https://doi.org/10.12973/eurasia.2014.1218 a.

[10] N. Croft, A. Dalton, M. Grant. Overcoming Isolation in Distance Learning: Building a Learning Community through Time and Space, Journal for Education in the Built Environment, Vol.5, No.1, pp. 27-64, 2010. https://doi.org/10.11120/jebe.2010.05010027.

[11] L. Vygotsky. Interaction Between Learning and Development. In M. Gauvain \& M. Cole (Eds.), Mind and Society (pp. 29-36). W.H. Freeman and Company, 1978.

[12] N. Erdogan. Sociocultural Perspective of Science in Online Learning Environments, International Journal of Education in Mathematics, Science and Technology, Vol.4, No.3, pp. 247-259, 2016. https://doi.org/10.18404/ijemst.20679.

[13] D. M. Barry, H. Kanematsu. Teaching During the Covid-19 Pandemic, Issue June, p. 6, Clarkson University, 2020.

[14] M. Moallem. The Impact Of Synchronous And Asynchronous Communication Tools On Learner Self-Regulation, Social Presence, Immediacy, Intimacy And Satisfaction In Collaborative Online Learning, The Online 
Journal of Distance Education and E-Learning, Vol.3, No.3, pp. 53-77, 2015. http://tojdel.net/pdf/v03i03/v03i03-08.pdf

[15] P. Ruano, L. L. Delgado, S. Picco, L. Villegas, F. Tonelli, M. Merlo, J. Rigau, D. Diaz, M, Masuelli. The Good, the Bad, and the Ugly of Distance Learning in Higher Education, Intech, tourism, 13, 2016. https://doi.org/http://dx.doi.org/1 $0.5772 / 57353$

[16] L. Cohen, L. Manion, K. Morrison. Research Methods in Education, Routledge, 2007.

[17] R. N. Emiliasari, I. S. Jubaedah. Lesson Planning in EFL Classroom: A Case Study in Lesson Plan Preparation and Implementation, Wiralodra English Journal, Vol.3, No.2, pp. 367-375, 2019. https://doi.org/10.31943/wej.v3i2.67

[18] A. Hatip. The Transformation Of Learning During Covid-19 Pandemic Towards The New Normal Era, International
Webinar on Education, pp. 18-28, 2020.

[19] B. Nadeak. The effectiveness of distance learning using social media during the pandemic period of covid-19: A case in universitas kristen indonesia, International Journal of Advanced Science and Technology, Vol.29, No.7, pp. 1764-1772, 2020.

[20] H. Biriyai, V. T. Emmah. Online Discussion Forum: A Tool for Effective Student-Teacher Interaction, International Journal of Applied Science-Research, Vol.1, No.3, pp. 111-116, 2014. https://doi.org/10.2139/ssrn.2525047

[21] A. Halawa, A. Sharma, J. Bridson, S. Lyon, D. Prescott, A. Guha, D. Taylor. Constructing Quality Feedback to the Students in Distance Learning: Review of the Current Evidence with Reference to the Online Master Degree in Transplantation, World Journal of Education, Vol.7, No.4, p. 117, 2017. https://doi.org/10.5430/wje.v7n4p117 